\title{
Toxicity of Anethole and the Essential Oils of Lemongrass and Sweet Marigold to the Parasitic Mite Varroa destructor and Their Selectivity for Honey Bee (Apis mellifera) Workers and Larvae
}

\author{
Qodratollah Sabahi, ${ }^{1,2}$ Mollah Md. Hamiduzzaman, ${ }^{2}$ Juan S. Barajas-Pérez, ${ }^{3}$ \\ Jose M. Tapia-Gonzalez, ${ }^{3}$ and Ernesto Guzman-Novoa $\mathbb{D}^{2}$ \\ ${ }^{1}$ Department of Plant Protection, College of Agriculture and Natural Resources, University of Tehran, Karaj 31587-77871, Iran \\ ${ }^{2}$ School of Environmental Sciences, University of Guelph, 50 Stone Road East, Guelph, ON, Canada N1G 2W1 \\ ${ }^{3}$ CUSUR, Universidad de Guadalajara, E. Arreola Silva 883, Centro, 49000 Ciudad Guzmán, JAL, Mexico
}

Correspondence should be addressed to Ernesto Guzman-Novoa; eguzman@uoguelph.ca

Received 21 November 2017; Accepted 29 March 2018; Published 6 May 2018

Academic Editor: Nguya K. Maniania

Copyright (C) 2018 Qodratollah Sabahi et al. This is an open access article distributed under the Creative Commons Attribution License, which permits unrestricted use, distribution, and reproduction in any medium, provided the original work is properly cited.

\begin{abstract}
This study examined the toxicity of anethole and that of the essential oils of lemongrass (Cymbopogon citratus) and sweet marigold (Tagetes lucida) to the mite Varroa destructor and to honey bee workers and larvae. Anethole was the most toxic compound to $V$. destructor $\left(\mathrm{LC}_{50}: 304.9 \mu \mathrm{g} / \mathrm{ml}\right)$, whereas Tagetes oil was the least toxic $\left(\mathrm{LC}_{50}: 1256.27 \mu \mathrm{g} / \mathrm{ml}\right)$. The most and least toxic compounds to worker bees were anethole and Tagetes oil with $\mathrm{LD}_{50} \mathrm{~s}$ of 35942 and $85381 \mu \mathrm{g} / \mathrm{ml}$, respectively. For larvae, Tagetes oil was the most toxic compound $\left(\mathrm{LD}_{50}: 9580.7 \mu \mathrm{g} / \mathrm{ml}\right)$ and anethole the least toxic $\left(\mathrm{LD}_{50}: 14518.0 \mu \mathrm{g} / \mathrm{ml}\right)$. Anethole and Cymbopogon oil had the highest selectivity ratios. The expression of $A C h E$, a gene that regulates the production of acetyl cholinesterase, a detoxifying enzyme, was not altered in bees treated with the plant compounds at $48 \mathrm{~h}$ post-treatment. This study showed that anethole and Cymbopogon oil have potential for controlling Varroa mites and seem to be relatively safe for larvae and adult honey bees.
\end{abstract}

\section{Introduction}

The mite Varroa destructor is responsible for widespread losses of honey bee colonies, particularly in North America [1-4]. V. destructor feeds on the hemolymph and fat body of its host and can transmit deadly viruses $[5,6]$. Colonies infested with $V$. destructor that are treated with miticides produce more honey than untreated colonies [7], but the frequent use of synthetic miticides has resulted in the development of resistance to many of these products in mite populations [8]. Synthetic miticides may also contaminate hive products [9]. Therefore, there is demand for new compounds with high miticidal activity that at the same time are safe for the bees, the environment, and nontarget species (including bees and humans). Plant essential oils and the components of these substances are attractive miticide candidates for controlling pests and diseases in hives because they meet most of these criteria [10-12]. Furthermore, many essential oils and their components exhibit considerable miticidal activity against $V$. destructor $[10]$.

Miticides are also toxic to bees to some degree [13]. Consequently, bees activate detoxification mechanisms when a pesticide is too toxic to them. One of these mechanisms results in the increased production of acetyl cholinesterase (AChE), an enzyme that regulates the concentration of acetylcholine at the synapses level of individuals exposed to pesticides such as carbamates and organophosphates [14], as well as to pyrethroids [15] and neonicotinoids [16-18]. Therefore, AChE activity is widely used as neurotoxicity biomarker. However, the activation of these mechanisms and the production of AChE are not well known for arthropods exposed to essential oils $[19,20]$. Additionally, the activation 
of detoxification mechanisms is energy demanding and costly to the bees, which may compromise their physiology and health. Thus, it is important that miticides are minimally toxic to bees and that they do not need to invest considerable resources in detoxification processes when exposed to miticides during Varroa mite control treatments.

This study examined the toxicity of anethole, an aromatic compound of the essential oil of anise (Pimpinella anisum), as well as that of the essential oils of lemongrass (Cymbopogon citratus) and sweet scented marigold (Tagetes lucida) to Varroa mites and honey bees. The main component of Cymbopogon citratus is the monoterpenoid geraniol, whereas that of Tagetes lucida is the aromatic phenylpropene estragole. Other researchers have reported on the pesticide properties of the plant compounds we tested. For example, anethole has shown toxicity to several insects [21, 22], nematodes [23], and mites [24]. Cymbopogon oil can kill mosquitoes [25] and mites [26]. Tagetes oil has evidenced pesticide activity against insects such as bedbugs [27] and against ticks [28]. Moreover, Tagetes oil has been tested against several pathogens of the honey bee, including the bacterium Paenibacillus larvae, the fungus Ascosphaera apis, and the mite V. destructor [29, 30]. However, this study is the first to evaluate the relative toxicity and selectivity of anethole and lemongrass oil on Varroa mites and on larvae and adult honey bees. The expression of AChE, the gene that regulates the production of the detoxifying enzyme AChE, was also analyzed in bees treated with these compounds.

\section{Materials and Methods}

2.1. Compounds. Anethole (technical grade) was obtained from Sigma-Aldrich (St. Louis, MO, USA), whereas the essential oils of Cymbopogon citratus and Tagetes lucida were obtained from plant tissues by steam distillation as per Ames and Matthews [31]. Tau-fluvalinate, used as positive control, was also obtained from Sigma-Aldrich.

2.2. Varroa Mite and Honey Bee Sources. The trials were conducted at the University of Guelph's Honey Bee Research Centre in Guelph, ON, Canada. Colonies headed by Buckfast queens were used as sources of mites and bees. The mites were obtained from adult bees [32] of three colonies that were heavily infested with $V$. destructor and that had not been treated with miticides for at least one year. Three other colonies provided adult bees and larvae. For adult bees, combs with emerging brood were caged and incubated $\left(33^{\circ} \mathrm{C}\right.$ and $60 \% \mathrm{RH}$ ) overnight to obtain newly emerged workers, and the same colonies provided the larvae for the experiments as described below.

2.3. Toxicity to $V$. destructor. After preliminary tests, six logarithmic interval concentrations of each compound (Table 1) were prepared in $1.5 \mathrm{ml}$ of HPLC grade acetone. Then, as per Gashout and Guzmán-Novoa [33], $0.5 \mathrm{ml}$ of each solution was placed into a $20 \mathrm{ml}$ glass scintillation vial (Fisher Scientific Ltd., Ottawa, ON, Canada) with a pipette, including acetone and tau-fluvalinate as controls. The vials were rolled out to distribute the solution on their inner walls. After the acetone evaporated (about $10 \mathrm{~min}$ ), the vials were capped. Five female mites were introduced into each vial with a fine paintbrush and left in the dark at room temperature $\left(26^{\circ} \mathrm{C}\right.$ and $\left.65 \% \mathrm{RH}\right)$. A total of 280 mites were used for each compound in eight replications. To determine the acute toxicity of each compound, the number of dead mites was recorded at $4 \mathrm{~h}$ post-treatment (hpt). A needle was used to touch the body of each mite. If the parasite did not move, it was assumed to be dead.

2.4. Toxicity to Honey Bee Workers and Larvae. The plant compounds and tau-fluvalinate were dissolved in 96\% ethanol to obtain the same concentrations as above and a topical assay was used to treat newly emerged workers as follows. Each bee received $5 \mu \mathrm{l}$ of solution of one treatment concentration on her prothorax with the aid of a micropipette. A total of 25 bees were treated per concentration for each compound and control bees were treated with ethanol. Groups of 25 treated bees were introduced into hoarding cages $(12.7 \times$ $8.5 \times 14.5 \mathrm{~cm}$ ) equipped with two $20 \mathrm{ml}$ gravity feeders, one containing $50 \%(\mathrm{w}: \mathrm{v})$ sugar: distilled water solution and the other containing distilled water. Then, the cages were held in an incubator at $33^{\circ} \mathrm{C}$ and $60 \% \mathrm{RH}$. Dead bees were counted at 24 and $48 \mathrm{hpt}$. Three trial replications were conducted.

For honey bee larvae, combs containing abundant third or fourth instar larvae were retrieved from the source colonies to treat them as per Gashout and Guzmán-Novoa [33]. Briefly, groups of 25 larvae were individually treated with $5 \mu \mathrm{l}$ of solution for each concentration per compound by placing the solution at the bottom of each cell with a micropipette. The outer edges of cells containing experimental larvae were painted with different colors with nontoxic markers (L551P2, Hunt Int., Mississauga, ON, Canada) to identify the treatments. The combs containing the larvae were returned to their respective hives after treatment. Mortality was determined at 24 and $48 \mathrm{hpt}$. Pearl white larvae were assumed to be alive whereas larvae with a brownish color or missing from cells due to the hygienic behavior of bees were assumed to be dead. Three trial replications were conducted.

2.5. Relative Selectivity Ratios. To assess safety margins of the natural compounds for the honey bee, relative selectivity ratios [34] were calculated by dividing the toxicity value of the host ( $\mathrm{LD}_{50}$ of worker or larvae) by that of the pest $\left(\mathrm{LC}_{50}\right.$ of $V$. destructor). These ratios permitted comparisons of the tested compounds relative to each other and to tau-fluvalinate.

2.6. Acetyl Cholinesterase Gene Expression. Real-time quantitative PCR (RT-qPCR) was used to measure the expression of $A C h E$ in samples of worker bees. About 15 bees were collected per treatment and per replicate at 0 and $48 \mathrm{hpt}$. The bees were placed in plastic bags and kept frozen at $-70^{\circ} \mathrm{C}$ for later RNA extraction.

After analyzing the toxicity of the compounds, control bees and the bees treated with the concentration closest to and within the $95 \%$ confidence limits of the $\mathrm{LD}_{50}$ value at $48 \mathrm{hpt}$ were used to measure the expression of $A C h E$ (the bees treated with $110 \mu \mathrm{g} / \mathrm{ml}$ of tau-fluvalinate, $34,000 \mu \mathrm{g} / \mathrm{ml}$ of anethole, and 60,000 $\mu \mathrm{g} / \mathrm{ml}$ of Cymbopogon or Tagetes oil). 
TABLE 1: Logarithmic interval concentrations of compounds were used for determining the lethal concentration $\left(\mathrm{LC}_{50}\right)$ or dose $\left(\mathrm{LD}_{50}\right)$ for Varroa destructor female mites and for worker or larvae of Apis mellifera, respectively. Actual concentrations are shown in the table.

\begin{tabular}{lccc}
\hline Products & Mite & Concentrations $(\mu \mathrm{g} / \mathrm{ml})$ & Larvae \\
\hline Anethole & $100,150,230,350,530,800$ & $25000,29400,34000,40000$, & $5000,7200,10200,14600$, \\
& & 47000,55000 & 21000,30000 \\
Cymbopogon oil & $160,230,340,500,720,1050$ & $7000,11600,20000,34000$, & $4000,7000,12000,20000$, \\
& & 60000,100000 & 35000,60000 \\
Tagetes oil & $200,320,500,800,1300,2000$ & $10000,18000,34000,60000$, & $3000,4000,5500,7700,10300$, \\
Tau-fluvalinate & $20,40,70,140,260,500$ & 110000,200000 & 14000 \\
& & $20,50,110,220,460,960$ & $50,110,220,460,960,2000$ \\
\hline
\end{tabular}

TABLE 2: Lethal concentration $\left(\mathrm{LC}_{50}\right)$ and $95 \%$ confidence limits $(\mathrm{CL})$ estimated for Varroa destructor female mites at $4 \mathrm{~h}$ after exposure to $0.5 \mathrm{ml} /$ vial of six concentrations of essential oil products and tau-fluvalinate.

\begin{tabular}{lccccccc}
\hline Compounds & $N$ & $\mathrm{LC}_{50}(\mu \mathrm{g} / \mathrm{ml})$ & $95 \% \mathrm{CL}$ & Slope $\pm \mathrm{SE}$ & Intercept & $X^{2}$ & $\mathrm{df}$ \\
\hline Anethole & 280 & 304.94 & $225.24-357.87$ & $3.35 \pm 0.86$ & -3.31 & 26.70 & 46 \\
Cymbopogon oil & 280 & 474.13 & $349.86-592.17$ & $2.98 \pm 0.39$ & -2.97 & 59.65 & 46 \\
Tagetes oil & 280 & 1256.27 & $1018.54-1578.25$ & $1.92 \pm 0.27$ & -0.97 & 32.89 & 46 \\
tau-fluvalinate & 280 & 80.43 & $55.76-106.42$ & $1.71 \pm 0.24$ & 1.75 & 28.23 & 46 \\
\hline
\end{tabular}

Total RNA was extracted by homogenizing each composite sample of 15 bees per treatment in extraction buffer as per Chen et al. [35]. The amount and concentration of RNA were determined with a spectrophotometer (Nanovue GE Healthcare, Cambridge, UK) and cDNA was synthesized from the RNA using a cDNA synthesis kit (Revert Aid, Fermentas Life Sciences, Burlington, ON, Canada) according to the manufacturers protocol.

Each PCR reaction of $20 \mu \mathrm{L}$ consisted of $2 \mu \mathrm{L}$ of cDNA template, $10 \mu \mathrm{L}$ of SYBR Green/ROX/qPCR Super Mix (Thermo Scientific, Mississauga, ON, Canada), $0.6 \mu \mathrm{L}$ of each specific primer at a concentration of $300 \mathrm{nM}$, and $6.8 \mu \mathrm{L}$ of nuclease-free $\mathrm{H}_{2} \mathrm{O}$. The qRT-PCR reactions were performed in 96-well plates (Diamed ${ }^{\circledR}$, Mississauga, ON, Canada) with a BioRad CFX96 (Bio-Rad Laboratories, Mississauga, ON, Canada) thermocycler. The target gene primers used in this study were designed with the Primer-BLAST tool and then verified for hairpin loops and dimers with Gene Runner (Hasting Software Inc., New York, USA) after obtaining and aligning $A C h E$ sequences from the NCBI (Accession Number NC_007077.3). The forward and reverse primers used were GGACATAATGGCGGCTACGA and CTCCTCGCTGTTCGTGAAGT, respectively. The reference gene used was RpS5 [36]. The primers were ordered from Laboratory Services of the University of Guelph (Guelph, ON, Canada).

All reactions were set up in triplicate for each of three biological replicates. A two-step cycling protocol was followed, using a Uracil-DNA glycosylase pretreatment at $50^{\circ} \mathrm{C}$ for $2 \mathrm{~min}$, an initial denaturation at $95^{\circ} \mathrm{C}$ for $10 \mathrm{~min}$, and 40 cycles of $15 \mathrm{~s}$ at $95^{\circ} \mathrm{C}$ and $60 \mathrm{~s}$ at $60^{\circ} \mathrm{C}$. A negative control using nuclease-free $\mathrm{H}_{2} \mathrm{O}$ instead of $\mathrm{cDNA}$ and a positive control were included in each qRT-PCR run. The efficiency of the primers to optimize qPCR conditions was near $100 \%$ and was determined with standard curves from 10 -fold serial dilutions using 300 bp synthetic gene fragments (gBlocks, Integrated DNA technologies, Iowa, USA), which included the sequence of the forward primer, the amplicon sequence, and the reverse primer. AChE transcript abundance was quantified relative to the reference gene according to the $2^{-\Delta \Delta}$ (Livak) method [37] using the control as the calibrator. The Bio-Rad CFX Manager ${ }^{\circledR}$ software (Bio-Rad Laboratories, Mississauga, ON, Canada) was used to calculate the expression ratio.

2.7. Statistical Analyses. Data on mite, worker, and larvae mortality were subjected to probit analyses using the PoloPlus software [38] to estimate the $50 \%$ lethal concentration $\left(\mathrm{LC}_{50}\right)$ of mites and the $50 \%$ lethal dose $\left(\mathrm{LD}_{50}\right)$ of workers and larvae, as well as slopes and 95\% confidence intervals of the different compounds. The PoloPlus program was also used to compare the slopes of dose-response lines of the compounds. Data on abundance of $A C h E$ transcripts were $\log 10$ transformed and then subjected to ANOVA and to LSD tests when significance was detected.

\section{Results}

3.1. Toxicity to $V$. destructor. Anethole had the lowest $\mathrm{LC}_{50}$ $(304.9 \mu \mathrm{g} / \mathrm{ml})$ of the natural compounds tested against $V$. destructor, although its toxicity was not significantly different to that of Cymbopogon oil. Cymbopogon and Tagetes oils were ranked 2 nd and 3rd, respectively, and differed in toxicity to $V$. destructor from each other. Tau-fluvalinate was significantly more toxic to $V$. destructor than the three natural compounds with an estimated $\mathrm{LD}_{50}$ of $80.44 \mu \mathrm{g} / \mathrm{ml}$ (Table 2).

Parallel comparisons of the slopes of dose-response lines revealed no significant differences between anethole and Cymbopogon oil $\left(X^{2}=0.28\right.$, df $=1$, and $\left.p=0.599\right)$, but anethole had a significantly higher dose-response than Tagetes oil $\left(X^{2}=5.49, \mathrm{df}=1\right.$, and $\left.p=0.019\right)$ and taufluvalinate $\left(X^{2}=7.78, \mathrm{df}=1\right.$, and $\left.p=0.005\right)$. No differences in dose-response were found between Tagetes oil and taufluvalinate $\left(X^{2}=0.37, \mathrm{df}=1\right.$, and $p=0.544$; Figure $\left.1(\mathrm{a})\right)$. 


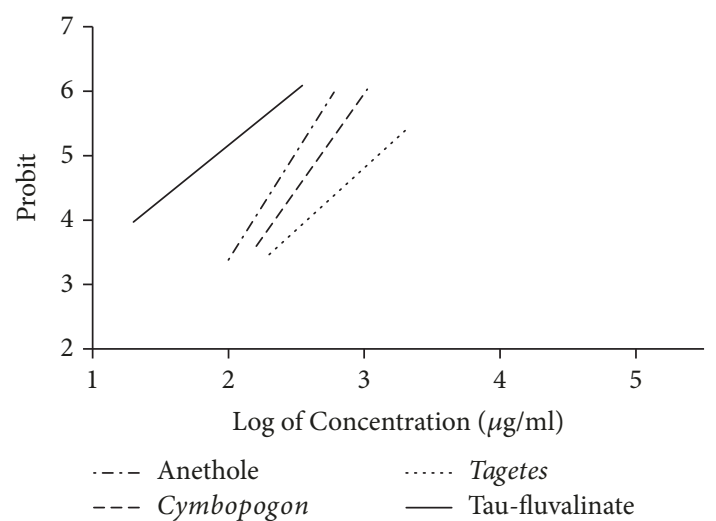

(a)

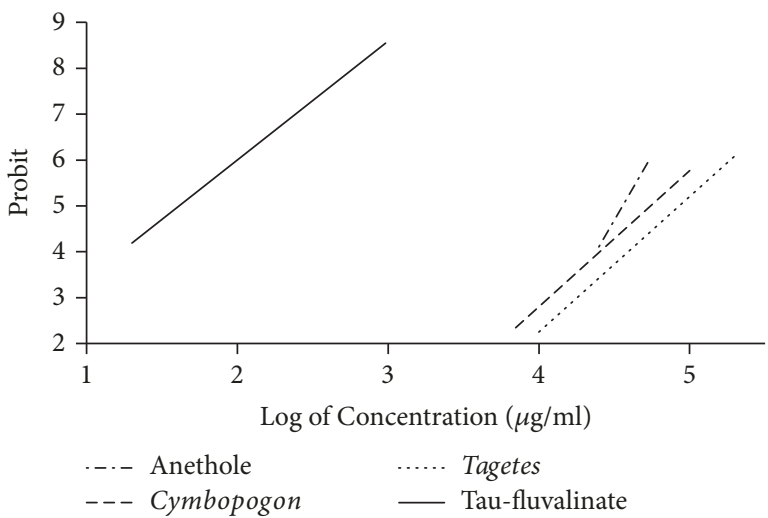

(b)

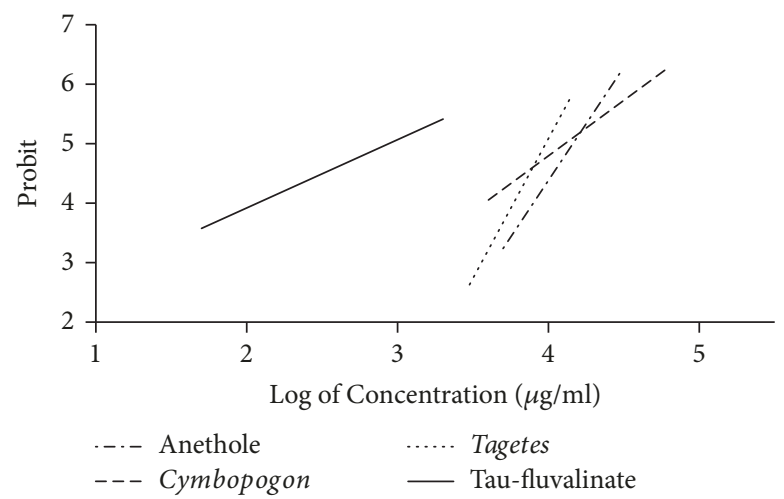

(c)

Figure 1: Dose-response lines of plant products or tau-fluvalinate for (a) Varroa destructor female mites when exposed for $4 \mathrm{~h}$ to $0.5 \mathrm{ml}$ of plant compounds using a vial assay, (b) Apis mellifera workers $24 \mathrm{~h}$ after a topical treatment with $5 \mu \mathrm{l}$ of plant compounds, and (c) Apis mellifera larvae $24 \mathrm{~h}$ after a topical treatment with $5 \mu \mathrm{l}$ of plant compounds.

3.2. Toxicity to Honey Bee Workers and Larvae. The most and least toxic natural compounds to newly emerged workers were anethole and Tagetes oil, respectively, with $\mathrm{LD}_{50 \mathrm{~s}}$ differing significantly at both 24 and $48 \mathrm{hpt}$. The toxicity of Cymbopogon oil to bees was not significantly different to that of anethole or Tagetes oil, whereas tau-fluvalinate was significantly more toxic to worker bees than the three natural compounds by at least 207 times (Table 3). Conversely, for larvae, Tagetes oil was the most toxic of the natural compounds, whereas anethole was the least toxic at both 24 and $48 \mathrm{hpt}$. The $\mathrm{LD}_{50}$ values for Cymbopogon oil were intermediate between anethole and Tagetes oil, but did not differ with any of them in toxicity to honey bee larvae. However, tau-fluvalinate was significantly more toxic to the larvae than the three natural compounds at both time points (Table 3). Its toxicity to honey bee larvae was nearly 11 times higher than that of Tagetes oil.

For worker bees, anethole had a significantly higher doseresponse than Cymbopogon oil $\left(X^{2}=28.46, \mathrm{df}=1\right.$, and $p<$ $0.001)$, Tagetes oil ( $X^{2}=24.89, \mathrm{df}=1$, and $\left.p<0.001\right)$, and tau-fluvalinate $\left(X^{2}=44.53, \mathrm{df}=1\right.$, and $\left.p<0.001\right)$. However, no differences were found between the slopes of the doseresponse lines for Cymbopogon and Tagetes oil $\left(X^{2}=0.01\right.$, $\mathrm{df}=1$, and $p=0.91)$ or between those for Cymbopogon oil and tau-fluvalinate $\left(X^{2}=0.86, \mathrm{df}=1\right.$, and $p=0.354$; Figure $1(b))$. For larvae, anethole had a significantly higher doseresponse than Cymbopogon oil $\left(X^{2}=32.84, \mathrm{df}=1\right.$, and $p<$ $0.001)$ or tau-fluvalinate $\left(X^{2}=54.05, \mathrm{df}=1\right.$, and $\left.p<0.001\right)$, but no significant difference was found between the slopes of the dose-response lines for anethole and Tagetes oil $\left(X^{2}=\right.$ $1.56, \mathrm{df}=1$, and $p<0.211$; Figure $1(\mathrm{c}))$.

3.3. Relative Selectivity Ratios. The relative selectivity ratios calculated for anethole, Cymbopogon oil, Tagetes oil, and taufluvalinate were $117.9,115.7,68.0$, and 2.2 , respectively, in the case of adult bees and 47.6, 27.2, 7.6, and 10.9, respectively, in the case of bee larvae.

3.4. Acetyl Cholinesterase Gene Expression. The relative abundance of $A C h E$ transcripts at $48 \mathrm{hpt}$ was significantly higher in tau-fluvalinate treated bees $(27.34 \pm 13.4$ fold change) than in bees from other treatments. There were no significant differences in the expression level of this gene between bees of the control, anethole, Cymbopogon, and Tagetes oil treatments at $0 \mathrm{hpt}$ or at $48 \mathrm{hpt}$, indicating that only tau-fluvalinate was 


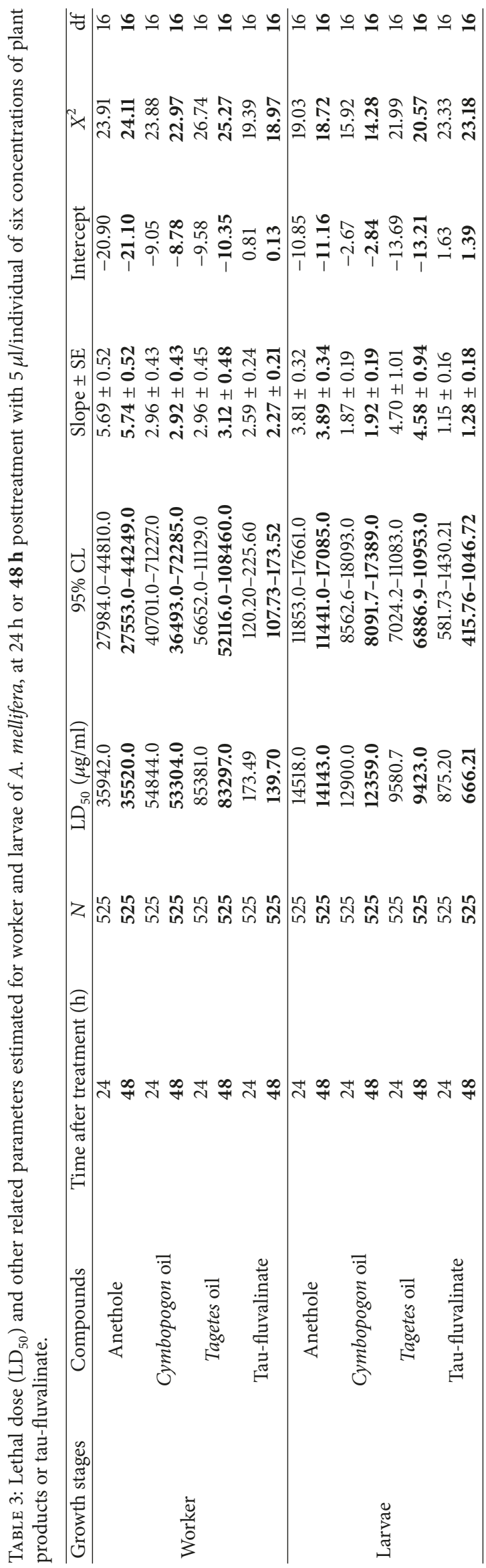




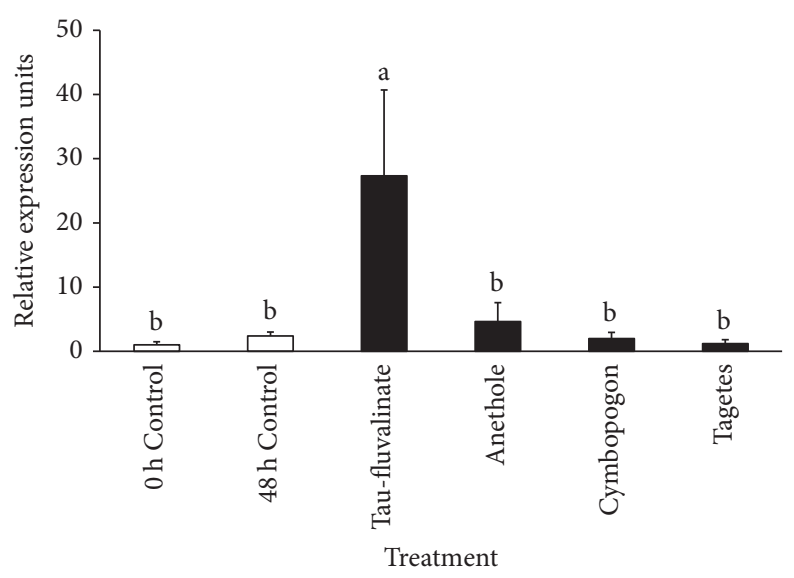

FIGURE 2: Relative expression of the gene AChE using qRT-PCR in Apis mellifera workers at 0 and $48 \mathrm{~h}$ posttreatment with $5 \mu \mathrm{l}$ of taufluvalinate $(110 \mu \mathrm{g} / \mathrm{ml})$, anethole $(34,200 \mu \mathrm{g} / \mathrm{ml})$, Cymbopogon oil $(60,000 \mu \mathrm{g} / \mathrm{ml})$, and Tagetes oil $(60,000 \mu \mathrm{g} / \mathrm{ml})$. Control bees were treated with solvent (ethanol). Different letters indicate significant differences of means based on analysis of variance and Fisher protected LSD tests $(n=45)$ performed with log-transformed data.

associated with elevated expression of $A \operatorname{ChE}\left(F_{5,12}=4.27\right.$, $p<0.01$; Figure 2).

\section{Discussion}

This study was carried out to test the potential of some plant compounds for controlling Varroa mites as well as to determine their relative toxicity to honey bee workers and larvae. Both anethole and Cymbopogon oil showed significant effects on the mites and at the same time high selectivity and safety margins for the honey bee. The miticidal effect of anethole had been demonstrated before [24], but its relative toxicity and selectivity had never been determined for $V$. destructor and honey bee larvae and adults. In this study, anethole's dose-response and toxicity to $V$. destructor was significantly higher than that of Tagetes oil (4.1 times) and similar to that of Cymbopogon oil. Its toxicity to worker bees was also significantly higher than that of Tagetes oil (2.4 times) but not different to that of Cymbopogon oil. Conversely, anethole was less toxic than Tagetes oil for honey bee larvae and Cymbopogon oil had intermediate toxicity. By comparison, tau-fluvalinate was 3.8 times more toxic to Varroa mites than anethole, but it also resulted in being 17 times more toxic to larvae and at least 207 times more toxic to adult bees than anethole. Additionally, the selectivity ratios for anethole were the highest of all compounds tested. From the above results, it can be concluded that anethole has the highest potential as varroacide among the compounds tested and demonstrated large safety margins for honey bees. It thus could be recommended for further testing in hives.

Anethole is currently used as a flavoring or fragrance agent in the food industry and there are no safety concerns for human health [39]. However, its possible effects on odor or taste of honey should be considered. Anethole is isolated from star anise essential oil and is also produced synthetically from sulfate turpentine oils. The annual production of star anise essential oil for isolation of anethole exceeds 3000 tons [40].
Therefore, it can be assumed to be economically available should a new market be created due to its varroacidal activity.

The toxicity of Cymbopogon oil to $V$. destructor and to honey bee workers and larvae was similar to that of anethole. However, it had slightly lower relative selectivity ratios than anethole. Still, it was much higher than the ratios for Tagetes oil and tau-fluvalinate, which also makes it a potentially effective and safe varroacidal candidate for testing at the hive level. Further purification of Cymbopogon oil and separation of its active ingredients may enhance its varroacidal effect. In previous studies, Cymbopogon oil has been found to have miticidal activity [26] and it is known that citral, its main component, may kill Varroa mites [41]. However, this is the first study to demonstrate its varroacidal activity and low toxicity to adult bees and larvae.

Tagetes oil was significantly less toxic to Varroa mites than tau-fluvalinate and the other two plant compounds tested in this study. It was also the least toxic of the compounds to adult bees, but conversely, second to tau-fluvalinate, Tagetes oil was the most toxic of the compounds to larvae. Furthermore, it was the least selective of the plant compounds tested when toxicity results on larvae were used in the calculations. Therefore, it would rank lower than anethole and Cymbopogon oil as potential varroacidal compound. It is puzzling why Tagetes oil was particularly toxic to honey bee larvae. However, studies in other insects have shown that tissues of Tagetes plants contain (5E) ocimenone and $\alpha$-terthienyl, which have shown potent larvicidal effects against mosquitoes [25]. The mode of action of $\alpha$-terthienyl is related to its interference with antioxidant defense systems in the larvae of organisms exposed to this plant insecticide [42]. The toxicity of the essential oil of T. minuta to Varroa mites and adult honey bees had been assessed previously by Eguaras et al. [29] under a potter tower. They estimated a $\mathrm{LC}_{50}$ of $4.37 \mathrm{mg} / \mathrm{cage}$ for Varroa mites and $13.6 \mathrm{mg} /$ cage for worker bees. However, due to different methods of evaluation, it is impossible to 
directly compare their result with ours, although both studies revealed the selective property of the oil for adult bees.

We found an elevated expression of $A C h E$ in bees $48 \mathrm{~h}$ after being treated with tau-fluvalinate but not with the plant compounds (Figure 2). This increase in gene expression could be explained as an adaptive mechanism with which bees counteract the AChE inhibitory effect of tau-fluvalinate. Similar results were reported by Badiou et al. [15] when they exposed honey bees to another pyrethroid, deltamethrin. Our results for tau-fluvalinate exposure agree with the notion that $A C h E$ is likely associated with stress responses. AChE increases when worker bees are stressed, for example, under conditions of poor pollen availability, and is inhibited when pollen is available and brood rearing is induced [43]. Therefore, it is possible that only tau-fluvalinate had caused stress on the bees. The low toxicity of the plant compounds to adult honey bees relative to tau-fluvalinate found in this study might have also been related to the lack of changes in $A C h E$ expression in bees exposed to them and thus only bees exposed to tau-fluvalinate showed higher abundance of AChE transcripts. Alternatively, the unresponsiveness of $A C h E$ expression to the plant compounds may have been due to lack of specificity of these compounds to acetylcholine receptors. It is known that terpenoids such as thymol bind to octopamine or to GABA receptors [44, 45], although other studies have also found that essential oils components such as thymol and linalool alter the expression of $A C h E[19,20$, $27,46]$. Another potential hypothesis to explain the lack of effects of the plant compounds on $A C h E$ expression is that the compounds could have been quickly metabolized and thus did not show any apparent effect on the expression of $A C h E$ at $48 \mathrm{hpt}$. In any case, further investigation is warranted to discover why the plant compounds tested here did not affect $A C h E$ expression in adult bees.

\section{Conclusion}

Anethole and Cymbopogon oil showed potential for controlling Varroa mites and at the same time had low toxicity and considerable safety margins for larvae and adult honey bees. Further studies on the mode of action of these plant compounds and field trials testing them in hives are warranted. Such studies may lead to replacing hazardous chemicals with natural safe compounds in order to maintain healthy honey bee colonies and users of hive products.

\section{Conflicts of Interest}

The authors declare that they have no potential conflicts of interest in relation to the study in this paper.

\section{Acknowledgments}

The authors are grateful to Paul Kelly, Nuria Morfin, Nancy Bradbury, Stephanie Otto, Brooke Wallace, and David Stotesbury who provided assistance with research tasks. They thank Taylor Campbell for reviewing the manuscript. This study was partially funded by a grant from the Natural Sciences and Engineering Research Council of Canada (no. 386129389).

\section{References}

[1] P. G. Kevan, E. Guzman-Novoa, A. Skinner, and D. vanEnglesdorp, "Colony collapse disorder in Canada: do we have a problem?" Hive Lights, vol. 20, pp. 14-16, 2007.

[2] R. W. Currie, S. F. Pernal, and E. Guzmán-Novoa, "Honey bee colony losses in Canada," Journal of Apicultural Research, vol. 49, no. 1, pp. 104-106, 2010.

[3] E. Guzmán-Novoa, L. Eccles, Y. Calvete, J. McGowan, P. G. Kelly, and A. Correa-Benítez, "Varroa destructor is the main culprit for the death and reduced populations of overwintered honey bee (Apis mellifera) colonies in Ontario, Canada," Apidologie, vol. 41, no. 4, pp. 443-450, 2010.

[4] D. Vanengelsdorp, J. Hayes Jr., R. M. Underwood, D. Caron, and J. Pettis, "A survey of managed honey bee colony losses in the USA, fall 2009 to winter 2010," Journal of Apicultural Research, vol. 50, no. 1, pp. 1-10, 2011.

[5] S. J. Martin, "The role of varroa and viral pathogens in the collapse of honeybee colonies: A modelling approach," Journal of Applied Ecology, vol. 38, no. 5, pp. 1082-1093, 2001.

[6] R. Anguiano-Baez, E. Guzman-Novoa, M. M. Hamiduzzaman, L. G. Espinosa-Montaño, and A. Correa-Benítez, "Varroa destructor (mesostigmata: Varroidae) parasitism and climate differentially influence the prevalence, levels, and overt infections of deformedwing virus in honey bees (hymenoptera: Apidae)," Journal of Insect Science, vol. 16, no. 1, Article ID 33242, 2016.

[7] M. E. Arechavaleta-Velasco and E. Guzmán-Novoa, "Relative effect of four characteristics that restrain the population growth of the mite Varroa destructor in honey bee (Apis mellifera) colonies," Apidologie, vol. 32, no. 2, pp. 157-174, 2001.

[8] D. Sammataro, P. Untalan, F. Guerrero, and J. Finley, “The resistance of varroa mites (acari: Varroidae) to acaricides and the presence of esterase," International Journal of Acarology, vol. 31, no. 1, pp. 67-74, 2005.

[9] A. S. Bogdanov, "Contaminants of bee products," Apidologie, vol. 37, pp. 1-18, 2006.

[10] A. Imdorf, S. Bogdanov, R. I. Ochoa, and N. W. Calderone, "Use of essential oils for the control of Varroa jacobsoni Oud. in honey bee colonies," Apidologie, vol. 30, no. 2-3, pp. 209-228, 1999.

[11] C. Fassbinder, J. Grodnitzky, and J. Coats, "Monoterpenoids as possible control agents for Varroa destructor," Journal of Apicultural Research, vol. 41, no. 3-4, pp. 83-88, 2002.

[12] A. P. Melathopoulos, S. F. Pernal, E. Moller, W. Baumgartner, and E. Guzman-Novoa, "A spring evaluation of thymol formulated in a sucrose dust for the control of Varroa destructor, a parasite of the honey bee (Apis mellifera) in Alberta, Canada," Science of Bee Culture, vol. 2, pp. 2-6, 2010.

[13] R. M. Johnson, M. D. Ellis, C. A. Mullin, and M. Frazier, "Pesticides and honey bee toxicity - USA," Apidologie, vol. 41, no. 3, pp. 312-331, 2010.

[14] A. H. Walker, S. P. Hopkin, R. M. Sibly, and D. B. Peakall, Principles of Ecotoxicology, Taylor and Francis, London, UK, 2nd edition, 2001.

[15] A. Badiou, M. Meled, and L. P. Belzunces, "Honeybee Apis mellifera acetylcholinesterase-A biomarker to detect deltamethrin exposure," Ecotoxicology and Environmental Safety, vol. 69, no. 2, pp. 246-253, 2008.

[16] M. Boily, B. Sarrasin, C. DeBlois, P. Aras, and M. Chagnon, "Acetylcholinesterase in honey bees (Apis mellifera) exposed to 
neonicotinoids, atrazine and glyphosate: Laboratory and field experiments," Environmental Science and Pollution Research, vol. 20, no. 8, pp. 5603-5614, 2013.

[17] M. Alburaki, S. Boutin, P.-L. Mercier, Y. Loublier, M. Chagnon, and N. Derome, "Neonicotinoid-coated Zea mays seeds indirectly affect honeybee performance and pathogen susceptibility in field trials," PLoS ONE, vol. 10, no. 5, Article ID e0125790, 2015.

[18] O. Samson-Robert, G. Labrie, P.-L. Mercier, M. Chagnon, N. Derome, and V. Fournier, "Increased Acetylcholinesterase Expression in Bumble Bees During Neonicotinoid-Coated Corn Sowing," Scientific Reports, vol. 5, Article ID 12636, 2015.

[19] S. Keane and M. F. Ryan, "Purification, characterisation, and inhibition by monoterpenes of acetylcholinesterase from the waxmoth, Galleria mellonella (L.)," Insect Biochemistry and Molecular Biology, vol. 29, no. 12, pp. 1097-1104, 1999.

[20] W. Blenau, E. Rademacher, and A. Baumann, "Plant essential oils and formamidines as insecticides/ acaricides: What are the molecular targets?” Apidologie, vol. 43, no. 3, pp. 334-347, 2012.

[21] K.-S. Chang and Y.-J. Ahn, "Fumigant activity of (E)-anethole identified in Illicium verum fruit against Blattella germanica," Pest Management Science, vol. 58, no. 2, pp. 161-166, 2002.

[22] I.-K. Park, K.-S. Choi, D.-H. Kim et al., "Fumigant activity of plant essential oils and components from horseradish (Armoracia rusticana), anise (Pimpinella anisum) and garlic (Allium sativum) oils against Lycoriella ingenua (Diptera: Sciaridae)," Pest Management Science, vol. 62, no. 8, pp. 723-728, 2006.

[23] Y. Oka, S. Nacar, E. Putievsky, U. Ravid, Z. Yaniv, and Y. Spiegel, "Nematicidal activity of essential oils and their components against the root-knot nematode," Journal of Phytopathology, vol. 90 , no. 7, pp. 710-715, 2000.

[24] H.-S. Lee, "Food protective effect of acaricidal components isolated from anise seeds against the stored food mite, Tyrophagus putrescentiae (Schrank)," Journal of Food Protection, vol. 68, no. 6, pp. 1208-1210, 2005.

[25] M. M. M. Marques, S. M. Morais, Í. G. P. Vieira et al., "Larvicidal activity of tagetes erecta against aedes aegypti," Journal of the American Mosquito Control Association, vol. 27, no. 2, pp. 156158, 2011.

[26] V. B. Vicentini, D. Pratissoli, V. T. de Queiroz et al., "Ethanol extract of Cymbopogon winterianus on mortality and number of eggs of Tetranychus urticae," Ciência Rural, vol. 45, no. 7, pp. 1154-1159, 2015.

[27] F. A. S. Politi, J. D. Nascimento, A. A. da Silva et al., "Insecticidal activity of an essential oil of Tagetes patula L. (Asteraceae) on common bed bug Cimex lectularius L. and molecular docking of major compounds at the catalytic site of ClAChE1," Parasitology Research, vol. 116, no. 1, pp. 415-424, 2017.

[28] R. Andreotti, M. V. Garcia, R. C. Cunha, and J. C. Barros, "Protective action of Tagetes minuta (Asteraceae) essential oil in the control of Rhipicephalus microplus (Canestrini, 1887) (Acari: Ixodidae) in a cattle pen trial," Veterinary Parasitology, vol. 197, no. 1-2, pp. 341-345, 2013.

[29] M. J. Eguaras, S. Fuselli, L. Gende et al., "An in vitro evaluation of tagetes minuta essential oil for the control of the honeybee pathogens paenibacillus larvae and ascosphaera apis, and the parasitic mite varroa destructor," Journal of Essential Oil Research, vol. 17, no. 3, pp. 336-340, 2005.

[30] S. R. Fuselli, S. B. G. de la Rosa, L. B. Gende, M. J. Eguaras, and R. Fritz, "Antimicrobial activity of some argentinean wild plant essential oils against paenibacillus larvae larvae, causal agent of American foulbrood (AFB)," Journal of Apicultural Research, vol. 45, no. 1, pp. 2-7, 2006.

[31] G. R. Ames and W. S. A. Matthews, "The distillation of essential oils," Tropical Science, vol. 10, pp. 136-148, 1968.

[32] V. Dietemann, F. Nazzi, S. J. Martin et al., "Standard methods for varroa research," Journal of Apicultural Research, vol. 52, no. 1, 2013.

[33] H. A. Gashout and E. Guzmán-Novoa, "Acute toxicity of Essential oils and other natural compounds to the parasitic mite, Varroa destructor, and to larval and adult worker honey bees (Apis mellifera L.)," Journal of Apicultural Research, vol. 48, no. 4, pp. 263-269, 2009.

[34] J. Stanley and G. Preetha, "Pesticide toxicity to non-target organisms," in Exposure, Toxicity and Risk Assessment Methodologies, pp. 1-502, Springer, Berlin, Germany, 2016.

[35] G. Y.-J. Chen, S. Jin, and P. H. Goodwin, "An improved method for the isolation of total RNA from Malva pusilla tissues infected with Colletotrichum gloeosporioides," Journal of Phytopatho$\log y$, vol. 148, no. 1, pp. 57-60, 2000.

[36] J. D. Evans, "Beepath: An ordered quantitative-PCR array for exploring honey bee immunity and disease," Journal of Invertebrate Pathology, vol. 93, no. 2, pp. 135-139, 2006.

[37] K. J. Livak and T. D. Schmittgen, "Analysis of relative gene expression data using real-time quantitative PCR and the $2^{\Delta \Delta}$ C(T) method," Methods, vol. 25, no. 4, pp. 402-408, 2001.

[38] LeOra Software PoloPlus, POLO for Windows, LeOra Software, Berkeley, Calif, USA, 2002.

[39] FAO/WHO, Trans-anethole, Evaluation of the Joint FAO/WHO Expert Committee on Food Additives (JECFA), 1998, http://apps .who.int/food-additives-contaminants-jecfa-database/chemical .aspx? chemID=2295 (accessed on 20 May 17).

[40] H. Surburg and J. Panten, "Common Fragrance and Flavor Materials: Preparation, Properties and Uses," Common Fragrance and Flavor Materials: Preparation, Properties and Uses, pp. 1358, 2016.

[41] P. J. Elzen, J. R. Baxter, G. W. Elzen, R. Rivera, and W. T. Wilson, "Evaluation of grapefruit essential oils for controlling Varroa jacobsoni and Acarapis woodi," The American Bee Journal, vol. 35, pp. 666-668, 2000.

[42] B. M. Hasspieler, J. T. Amason, and A. E. R. Downe, "Toxicity, localization and elimination of the phototoxic, a-terthienyl, in mosquito larvae," Journal of American Mosquito Control Associatuon, vol. 4, pp. 479-484, 1988.

[43] Y. H. Kim, J. H. Kim, K. Kim, and S. H. Lee, "Expression of acetylcholinesterase 1 is associated with brood rearing status in the honey bee, Apis mellifera," Scientific Reports, vol. 7, Article ID 39864, 2017.

[44] E. Enan, "Insecticidal activity of essential oils: octopaminergic sites of action," Comparative Biochemistry and Physiology - Part C: Toxicology \& Pharmacology, vol. 130, no. 3, pp. 325-337, 2001.

[45] C. M. Priestley, E. M. Williamson, K. A. Wafford, and D. B. Sattelle, "Thymol, a constituent of thyme essential oil, is a positive allosteric modulator of human GABA (A) receptors and a homo-oligomeric GABA receptor from Drosophila melanogaster," British Journal of Pharmacology, vol. 140, no. 8, pp. 13631372, 2003.

[46] H. Gashout, Effect of sub-lethal doses of synthetic and natural acaricides on honey bee (Apis mellifera L.) health, memory, behaviour and associated gene expression [Ph.D. Dissertation], University of Guelph, Canada, 2017. 


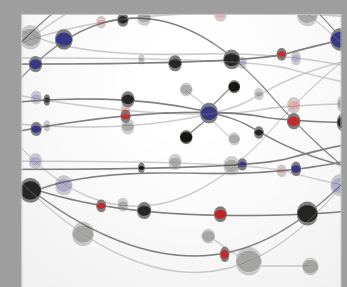

The Scientific World Journal
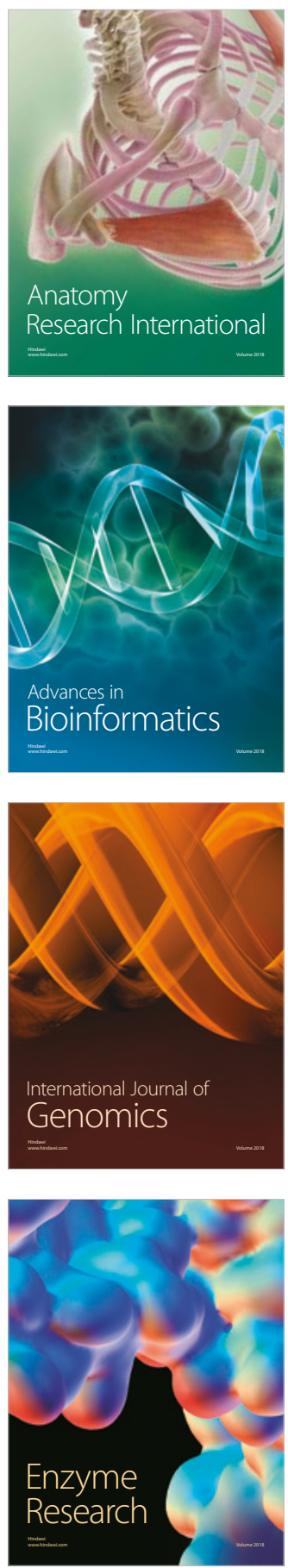
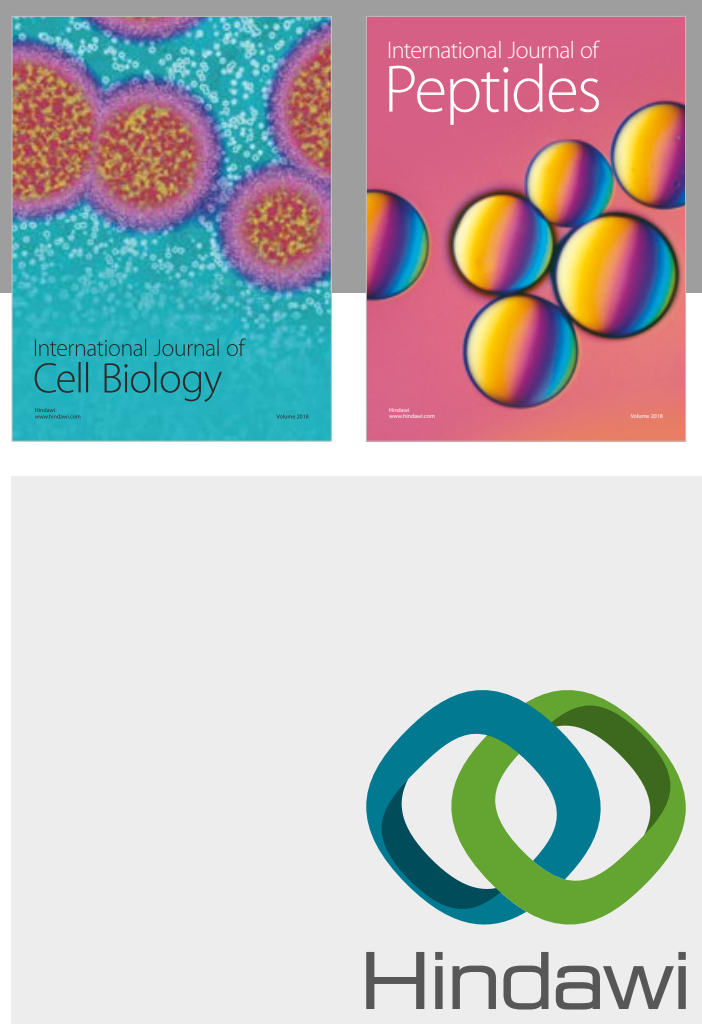

Submit your manuscripts at

www.hindawi.com
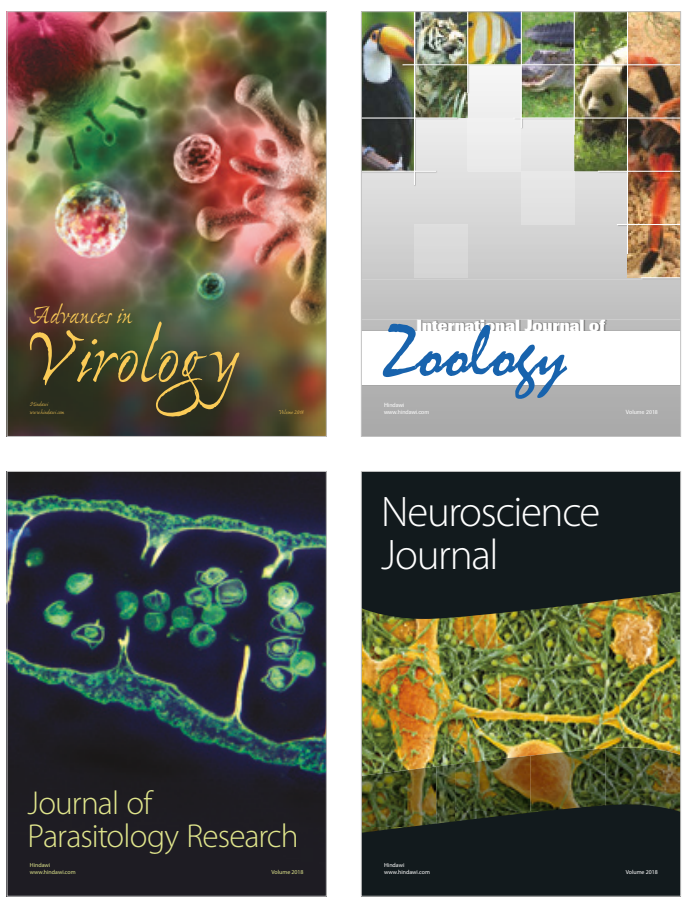
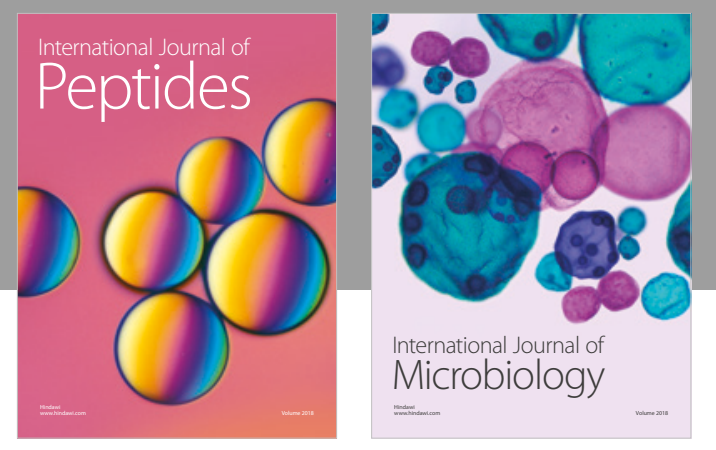

nternational Journal of Microbiology
Journal of
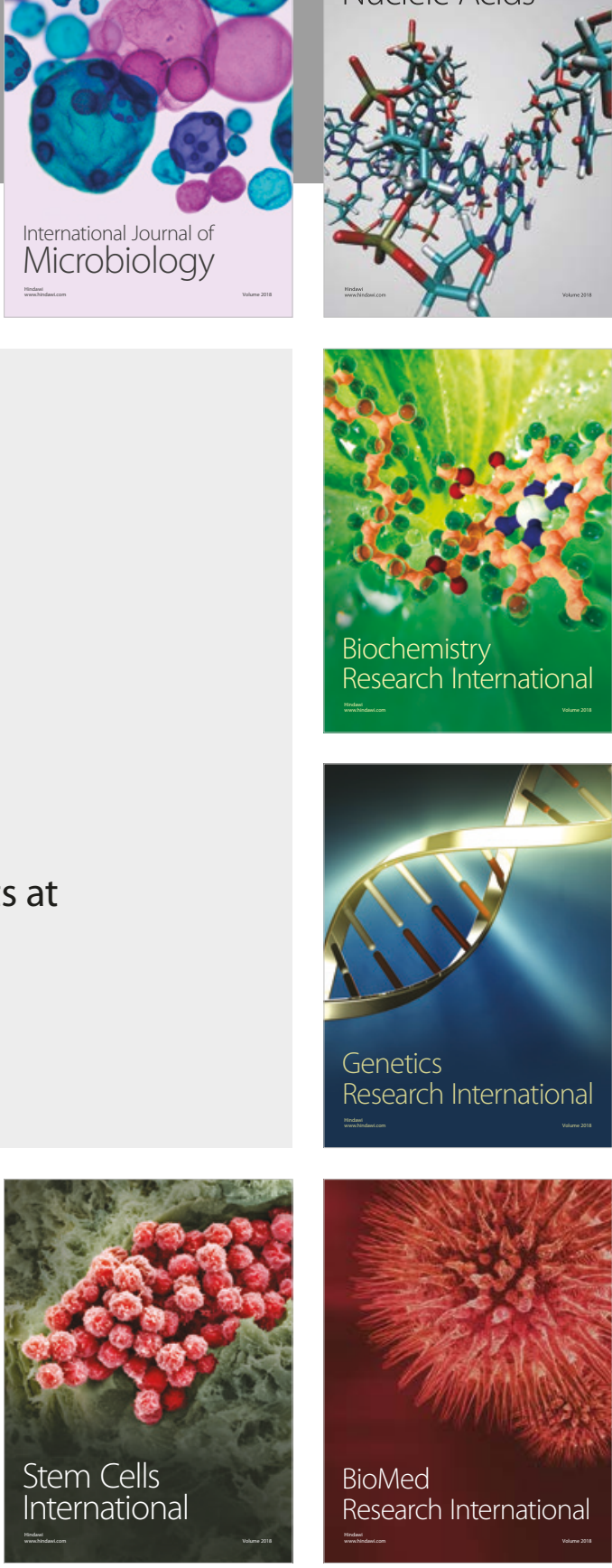
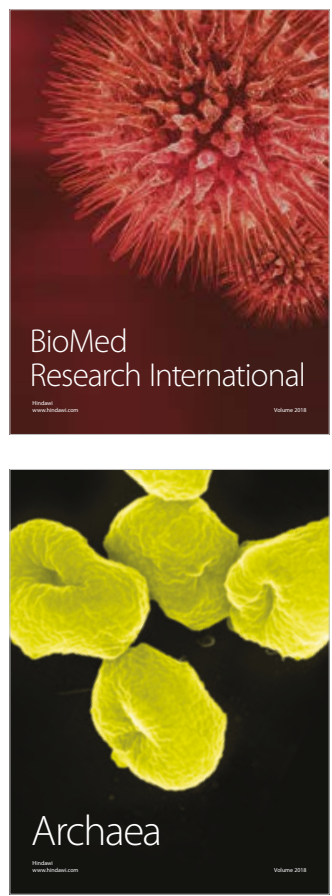